\title{
Nvivo Approach and Content Analysis in Media Flow Analysis and Alternative Selected Prime: Permatang Pauh By-Election
}

\author{
Mohd Hilmi Hamzah ${ }^{1}$, Norhafezah Yusof ${ }^{2}$, Azahar Kasim², Kamarudin Ngah $^{3}$, Jamaludin Mustaffa ${ }^{4}$ \& \\ Zaherawati Zakaria $^{5}$ \\ ${ }^{1}$ Centre For Policy Research and International Studies (cenPRIS), Universiti of Science Malaysia (USM), \\ Penang, Malaysia \\ ${ }^{2}$ School of Multimedia Technology and Communication (SMMTC), College of Arts and Sciences, Northern \\ University of Malaysia (UUM), Kedah, Malaysia \\ ${ }^{3}$ Pusat Penyelidikan Dasar dan Kajian Antarabangsa (CenPRIS), Universiti Sains Malaysia (USM), Pulau \\ Pinang, Malaysia \\ ${ }^{4}$ College of Arts and Science, Universiti Utara Malaysia, Sintok, Kedah, Malaysia \\ ${ }^{5}$ Faculty of Administrative Science \& Policy Studies, Universiti Teknologi MARA, P. O Box 187, Merbok, \\ Kedah Malaysia \\ Correspondence: Zaherawati Zakaria, Faculty of Administrative Science \& Policy Studies, Universiti Teknologi \\ MARA, P. O Box 187, 08400 Merbok, Kedah Malaysia. Tel: 60-4-456-2565. Email: \\ zaherawati@kedah.uitm.edu.my
}

Received: July 23, 2013 Accepted: August 21, 2013 Online Published: October 29, 2013

doi:10.5539/ass.v9n15p84

URL: http://dx.doi.org/ass.v9n15p84

\begin{abstract}
Nowadays, media seems to be important indicator in general election. It is due to political change in Malaysian general election in 2008. The usage of media through be-election can be a signal to political parties to plan their strategies and manifesto in future election. Therefore, the way of information disseminate and issues deliver by them will enhance the fruitful in political landscape in Malaysia. Thus, this study was conducted to identify issues featured in Utusan Malaysia, Berita Harian, Harakah and Suara Keadilan as well as the differences in the issues presented by the four newspapers during the Parliament Permatang Pauh election campaign period in 2008 . Agenda Setting Theory was used as the theoretical framework underlying this research. The study using the tree nodes analysis technique and the findings through qualitative analysis reveals 11 issues and three themes from the newspapers studied. The emerging issues were found consists of government formation, education, candidates, ethnic, elections, media, ruling party, Pakatan Rakyat, development, religion and security. The finding shows that the most prominent issue is about candidates. In terms of differences in how the four daily newspapers featuring equality issue most prominently displayed on different ideologies and views. The latter newspaper, however, was favourable in its reports on the Pakatan Rakyat political party. The findings based on Agenda Setting Theory indicates that the company shareholders and the newspaper editors had a heavy influence on the news reporting made by the four newspapers studied. In future research, the four newspapers should be free while reporting in order to have useful issues deliver to the public. They must have the proper rules and policy to ensure the transparency and adequate information will disperse accordingly.
\end{abstract}

Keywords: communication, media, newspapers, by-election

\section{Introduction}

In the present day, information is very important to the community because it is difficult to enjoy a safe and effective life without information. To keep being informed, citizens should always seek knowledge, especially through the mass media which constantly offers information and news related to religion, politics, economics, entertainment and so on. Media is one of the most important components of communication, whether communication is seen as a process or system. Without the media, the communication process is not likely to occur. Media brings message and the message also contains the 'meat' that we want to digest. These contents give the name and form to a message he wanted to be channeled. This message may be in the form of 
advertisement information, soliciting advice, litigation and so forth. In this respect, the media expressed as any form of 'tools' either concrete or abstract, which can be a medium to convey a message (Naim, 2006).

As a rapidly developing country, Malaysia is going through various efforts to develop mass media technology. But in an environment to revolutionize the media technology, a mass media that has a lot more relevance to this day is the newspaper. According to Noor Adzrah (2006), in line with the rapid progress in Malaysia, the newspaper is still set to be the main communication medium in dissemination of information and to increase knowledge when various social activities depend largely on newspaper reports. According to Vilashini, Azizah Mohd Yahya and Azliana (2010), although the world is full of advanced technology, the newspaper is still recognized as a key intermediate in mass communication and provide information to the public on various developments that occur every day.

Newspapers in Malaysia are divided in two, mainstream newspapers and alternative newspapers. Mainstream newspapers are usually owned by large companies which are closely linked to the ruling party and in accordance with the political agenda of the government alone, without allowing free debate or independent reports (independent) of the critics of government leaders (Fathi, 2002). While the alternative press media is usually connected with the opposition party's views, but the alternative press is actually bringing news from different angles or outside the range of scenarios of the mainstream media (Fathi, 2002).

When talking about the press, the news that often receives the attention of readers in Malaysia is news related to politics. According to Mohd Safar (1991), political news published by newspapers in Malaysia, most notable news reader from the economy, sports and others. Political news is news-oriented and contains serious political elements in it, such as news matters affecting the administration of the ruling government, political development, political leaders and opposition political issues (Mastura, 2004). This is because the press and political system of government need each other as a nation influenced by the media since then until now (Zahid, 2008; Hadi, 2002; Safar, 1996; Arabi, 1992; Everete, Arnold \& Donald, 1978).

Political news of interest to the Malaysian society today is news related to elections. Dissemination of political news of the election by the mass media is very important because all the information presented can influence society. Hayes (2008) and Abbe, Goodliffe, Herrnson and Peterson (2003), argue that the media can help candidates to highlight specific issues as an agenda for discussion during the campaign. This is because the issue can have an impact on the government's agenda as fundamental policy makers that can influence the readers (Lawrence \& Birkland, 2004; Kim, Scheuffele \& Shanahan, 2002).

At the last general election that took place in 2008, Pakatan Rakyat has mastered four states, which caused a political wave. In the history of Malaysian elections since 1969, for the first time the ruling party lost two-thirds of the seats in Parliament. Shortly after the general election-12 has occurred, a parliamentary election in Permatang Pauh was described by politicians as a starting point for Pakatan Rakyat to form a new government in the general election to the 13th Judgment (Manja, 2008). This is because the parliamentary election in Permatang Pauh becomes an element of political strategy than the previous election, which involved the death of candidates of the non-vacant seats. Indirectly, this political strategy turns into a framework of knowledge based on the pattern displayed by the media reporting.

Therefore, based on the discussion, this study was to observe the formation of the issue from two mainstream newspapers (Utusan Malaysia \& Berita Harian) and two alternative newspapers (Harakah \& Suara Keadilan) during the election campaign of Parliament Permatang Pauh 2008. The question is, what are the issues published by the press during the period of holding the election and what issues are shaped by the press during the election of an equality or vice versa? This is because the selection of the issue by the press is also very important because it can indirectly influence voting behavior. Generally, this study tends to examine news about the issues of elections in selected Malay newspapers during the campaign. In particular, this study aims to identify issues in the election of Parliament Permatang Pauh published in the newspapers (Utusan Malaysia, Berita Harian, Harakah and Suara Keadilan as well as to identify the different issues in the election of Parliament Permatang Pauh published by the four newspapers (Utusan Malaysia, Berita Harian, Harakah and Suara Keadilan).

\section{Literature Review}

Newspaper is the medium to show the reality and can remain as a reference (Agee, Ault \& Emery, 1997). McCombs and Shaw (1972) and McCombs (1997) state that the direct role of newspapers is to create the perception of society and make a decision. The ability of newspapers to provide an overview of the issues that happened is no doubt, because there had been some previous research by scholars who concluded that the media can provide information and in turn affect the formation of public perceptions about current issues that occur (McCombs \& Shaw, 1972). 
In Malaysia, the newspaper is a very popular reading material. There are papers in different languages: Malay, English, Chinese, Tamil, Bahasa Dusun and Iban. The newspapers published daily are known as daily newspapers such as Berita Harian, Utusan Malaysia, New Straits Times and Harian Metro while the weekly newspapers are published once a week or at certain days of the week (Mansor, 1995). Newspapers in Malaysia are divided in two, mainstream newspapers and alternative newspapers. Most mainstream newspapers are usually owned by large companies which reflect the ruling party's political agenda and alternative news media means it is connected to the opposition parties and their agendas but is actually an alternative media that brings news from different angles or outside the range of scenarios and the mainstream media (Fathi, 2002).

This is where it can be concluded that newspapers in Malaysia over to one side focusing on the partisan or party that has an interest in the company setting up the newspaper. This item without doubt is material to release political actors in promoting actors and parties in order to influence voters. According to Abdul Hadi (2002), Mohd Salleh (1994) Everrete, Arnold and Donald (1978), the press and political system of a government need each other as a nation influenced by the media since then until now. This relationship between the newspaper and politics is nothing new and began when the newspaper became the opinion journals in the dissemination of news in the 18th century, subsequently taking over the functions of political pamphlets, especially in connection with the government and the election of a government (Hadi, 2002; Salleh, 1994; Everrete, Arnold \& Donald, 1978).

The study of the press and the elections were mostly done by previous scholars, among them Abdul Latiff (1988) who focused on the role of media in the Federal election of 1959 and 1964 by making the Utusan Malaysia newspaper as the main focus of his study. The study found that Utusan Malaysia is more likely to be used by the government during the election campaign and the press has the same format as the Federal election coverage. Similarly, Ahmad Zahid (2008) has conducted a research to identify the BN manifesto as a Malay daily agenda during the election campaign of 1982, 1986, 1990, 1995 and 1999 using a content analysis approach using a sample of 50 copies of Utusan Malaysia and Berita Harian newspapers. The result of the study showed a total of 11 major themes which are often used in the BN manifesto, the political, foreign policy, development, economic, social, education, security, religion, welfare workers, agricultural and quality of life. Results obtained from this study also reinforce the Agenda Determination Theory as both newspapers showed a trend towards the practice of determining the agenda for a newspaper owned by the ruling party who want translate the agenda of the party in the newspaper coverage.

Ismail, Ngu and Saraswathy (2008) have carried out a study on issues related to the 2008 general election using content analysis of selected newspapers. The study found that news related to Barisan Nasional and Barisan Alternatif place their own coverage in local newspapers. The findings of this study showed that issues relating to political parties, candidates and campaign among the contesting parties have major coverage in most newspapers. While issues related to the weakness of opposition parties, Hindraf and the least religion is displayed. The most important purpose of any news or material displayed is to inform and lash out at their opponents. This situation coincided with the purpose of reporting news media ahead of the election, which is to introduce and "promote" candidates, criticizing and attacking the opponent.

In addition to the general election-related research conducted by scholars before, the study of elections is also done by researchers, such as the study conducted by the Department Research Ministry of Women (1991), which analyzed the Pantai Merdeka by election, on March 24, 1990. Some aspects of the electoral process have been addressed as the issues, the campaign process, results and performance of the contesting parties, Barisan Nasional and PAS. As expected, Barisan Nasional has maintained state seats, but the majority declined to 3.409 votes. Lower voting turnout (72.69 percent in 1986 and 68.12 percent in the election) and bankruptcy issues become the main cause of the reduced majority. Even the issue of bankruptcy is the only major issue that has been exploited fully by PAS through the media. On the other hand, the lack of a majority of National Front is considered as a victory for PAS. Election result would also be a sign that the combination of PAS and Semangat 46 is well received by the members and supporters of PAS.

According to Ibrahim, Shireen, Norshidah, Shaharuddin, Mat Zin, Yadman, S. Salahuddin, Zulkifli, Mujibu and Shu'aibi (2009) economic issues are widely discussed during the Parliament election campaign in Permatang Pauh, based on public opinion. People desire change, particularly with regards to the uncertain economic situation so that their lives are more secure.

In the meantime, according to Zulkanain, Mohammad Redzuan, Amer Saifude and Shaharudin (2008), on the question and the meaning behind the choice of Permatang Pauh by-election explained that the election has attracted the interest and attention of voters at the national level, including Sabah and Sarawak as the Penang 
government is dominated by the opposition coalition and the candidate is former Deputy Prime Minister of Malaysia some time ago. Datuk Seri Anwar Ibrahim's victory in Permatang Pauh parliamentary seat will give him a foothold in national politics again after almost ten years of waiting. His presence in parliament and position as leader of the opposition can give strength to the opposition alliance itself because Anwar is said to act and play a role as the unifying factor between the opposition parties at the national level, especially between DAP and PAS.

Abroad, a study undertaken by McCombs (1997) examined the influence of news television, advertising on television and newspapers on the image of the candidate of a political party in Spain in 1995. Findings of this study indicate that applying the mass media agenda setting theory (the second agenda setting theory) affects the voters in the general election and urbanization in Spain. Christian (2004) has studied the issue of elections in Taiwan through advertising in newspapers and television. The results also showed that 35 percent of the newspapers advertisements contain negative messages. The issues covered in the newspaper advertisement are different from the issues that aired on television commercials. The bulk of the party newspaper's ads referred to politicians. It can be concluded that each of the media brings their own agenda based on the owners before being presented to the reader.

Pamela and Gregory (2000) have studied the political process in the local press coverage of elections in the United States. The results showed that there were less broadcast coverage of the protests during the election campaign. However, other forms (most of the festivals and public speaking) received a lot of coverage by the newspapers.

When we examine the current situation of the election published by the media, it can be concluded that the use of the theory is very important to see the agenda displayed by the media today. Most of the previous studies related to media have made use of the election agenda theory that led to the determination of the general election, while the use of theoretical determination of the agenda that led to the election was less done. Therefore, this study will be done using the theory of the determination which will be synonymous with the agenda to see the pattern of election news reporting and how major newspapers set the agenda in which such determination is usually associated with the media agenda and is defined as an issue or news that the priority of either institutions, the media or political parties or at the public (Ismail, Ngu \& Saraswathy, 2008; Arabi, 1994; Cohen, 1963).

\section{Methodology}

This study uses the methodology of content analysis which is pioneered by Berelson in 1952. This technique shows the accuracy of the content of a message meaning to research done by external communications objective, systematic and quantitative (Berelson, 1971). In this study, the researchers used this method to identify the daily agenda on the issue of parliamentary elections in Permatang Pauh. Each news release relating to the election code was analyzed based on the form provided. Appropriate statement of Syed Arabi (2002), he said that the press or media content analysis is a method associated with the determination of the media agenda in the election. The research works which used the content analysis concerned with the formation of categories based on the problem, purpose and field of study. Study material is divided into groups according to further analysis. There are several basic principles that should be considered in the development category. It should be suitable to study or do not overlap extensively research material to be classified correctly (Bereslon, 1971). Categories of this study are classified as follows:

1) Newspaper: Utusan Malaysia, Berita Harian, Harakah and Suara Keadilan,

2) Issues: Government Formation, Education, Candidates, Ethnic, Election, Media, Rulling Party, Pakatan Rakyat, Development, Religion and Security.

Content analysis coding method requires a systematic and orderly manner. To ensure that it is reliably encoded, a reliability test was performed. According to Holsti (1969), the reliability test is a method to test again using the same procedures and data to ensure a similar response to research made available for the first time. At the beginning, before the pre-test coding is done, a total of 550 news items were taken in the four newspapers. However, a total of 76 news items were removed because of news that served more to the reports, articles and readers letters rather than issues that are the primary objective of the study. In summary it can be removed after an unrelated news item made of 474 news items used for the sample used for the pre-test is a systematic technique.

To analyze the data in this study, researchers used NVivo 8 software program (source, nodes, queries, model \& classification). The data obtained after the coding was done for the purpose of data analysis. After the generated findings, the next step is to use the model to demonstrate a holistic model which provides detailed sub-sub on the 
issues based on findings obtained from the tree nodes. The purpose of this analysis is to obtain an overview of issues and themes based on a qualitative analysis. This method is necessary to explain all the data. Of this amount, it can make a comparison between the four newspapers studied in the news coverage.

\section{Result of Findings}

\subsection{Overall Issues}

For a detailed explanation of the pattern formation issues, researchers used the approach of the tree nodes in NVivo 8 software. As mentioned by Kim, Scheuffele and Shanahan (2002), a study should form a news issue because the implications of the study indicated that the pattern of media agenda has connections with the pattern formation and the formation of perceptions of the news audience. In general, the findings of the analysis showed that there were 11 issues which are considered very significant in this study (Figure 1). These issues are government formation, education, candidates, ethnics, elections, media, ruling party, Pakatan Rakyat, development, security and religion.

The analysis conducted on the issue of candidates generally showed the most prominent issue of frequency is shown by the four newspapers, namely by 24.1 percent (114) news item. This was followed by security issues when the analysis carried out showed that the frequency is 17.9 per cent (85) news items displayed by the four newspapers studied and the third most prominent issue is the issue of elections to which were 16.5 percent (78) news items. While the issue that received the least media coverage that is displayed by three newspapers Suara Keadilan but does not display live issue during the campaign period specified. The result also showed that the total frequency of 1.3 per cent (6) news items displayed by the three newspapers. Figure 1 describes the study of pattern formation agenda of issues and often by the press.

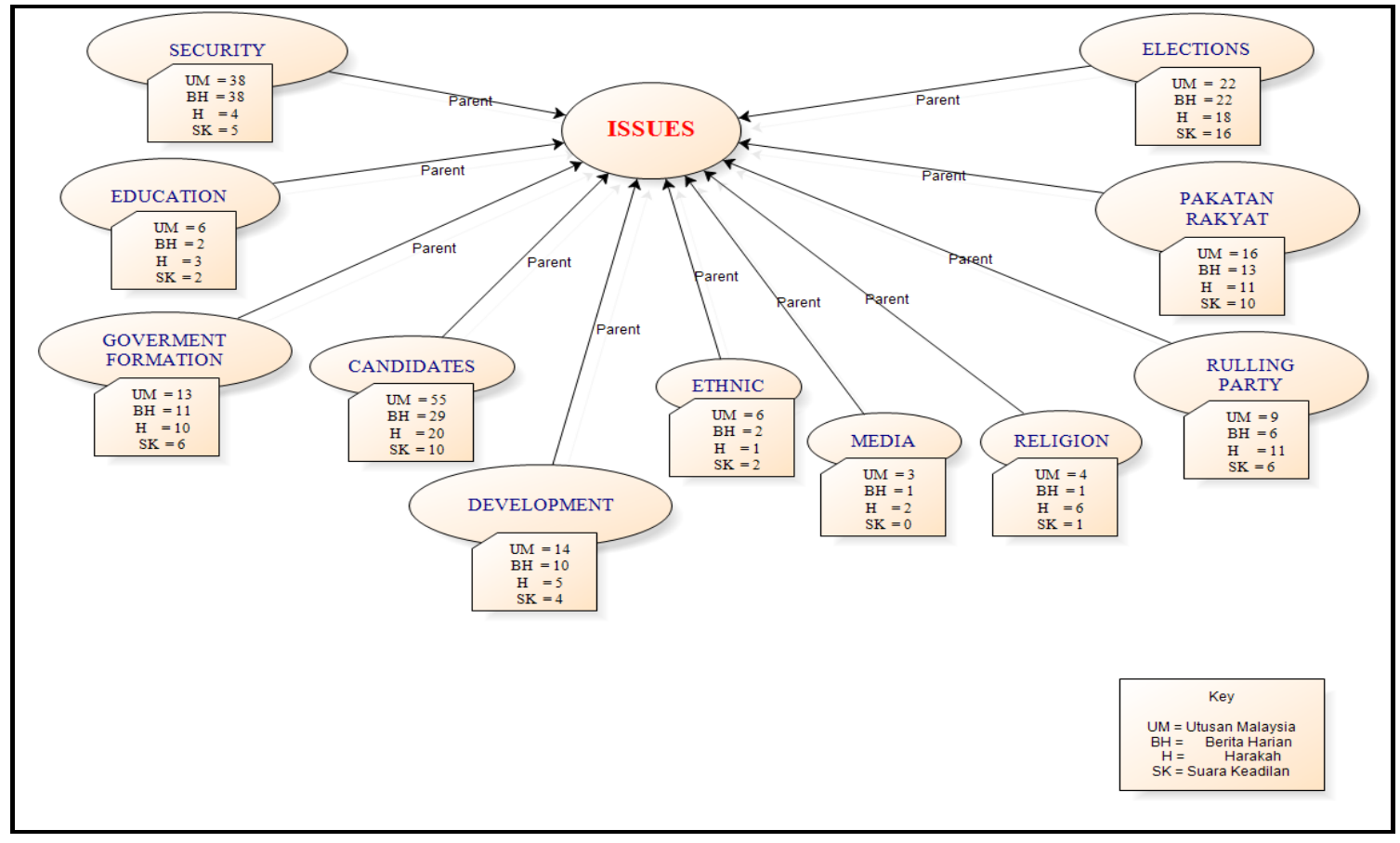

Figure 1. Pattern formation issues subcategories

\subsection{Issues According to Newspapers}

Table 1 shows the results for the frequency of issues displayed in the press. Based on the fraction of the press, which can be seen for Utusan Malaysia, the results showed that the most prominent issue is the issue of a candidate. The results showed that 29.6 per cent (55) of news item published by the newspaper was on the issue of candidates compared to other issues. While the media issue is an issue that received the least coverage by Utusan Malaysia, which is by 1.6 per cent (3) of news item published by Utusan Malaysia.

While in the Berita Harian newspaper, the results showed that security issues are most often displayed by the newspaper during the campaign period. This is in marked contrast to the other daily newspaper in the study of the Utusan Malaysia newspaper which highlighted the issues on candidates the most. The analysis showed that a 
28.1 per cent (38) of news item published by the Berita Harian newspaper on the issue of safety compared with other issues. While the issue of lack of attention by the media the issue of the newspaper is the same as the display produced by the Utusan Malaysia newspaper. The findings showed that 0.7 per cent (1) of news items displayed was on media issues.

For an alternative newspaper, the newspaper Harakah shows the issue most displayed by the newspaper is about the candidates, together with the display produced by the Utusan Malaysia newspaper. The results showed that 22 per cent (20) of news item published by the newspaper was on this issue compared to other issues during the campaign. While the issue of underserved by Harakah newspaper is on the issue of race by 1.1 percent (1) news items displayed. This situation is in contrast to the portrayal of the news shown in the two newspapers Utusan Malaysia and Berita Harian showed that most media issues of the underserved.

While the other alternative newspaper in this study, the Suara Keadilan newspaper showed that the issue of elections is the most dominant or most prominently displayed by the newspaper during the campaign period. 25.8 per cent (16) of election issues news items was published by the newspaper compared to other issues. While not directly related to media issues covered by the newspaper. This may be due to editors who feel that there is more news coverage of issues that play a warm again so that readers are interested in the views.

In summary, the results show that the issues most prominent in all four newspapers studied are entirely different, except for Utusan Malaysia and Harakah who share the most prominent issues, which was issues relating to the candidates. But different in Berita Harian and Suara Keadilan newspapers as the most salient issues highlighted by the Berita Harian newspaper is about safety issues while the Suara Keadilan newspaper tend to focus on election issues as its main agenda to be displayed. In terms of issues that are most underserved areas, it can thus be concluded that the two mainstream newspapers show similarities in terms of news displayed, the issue of media attention during the campaign period, compared with other issues. While in the press about the issue of less Harakah shown by the paper is on the issue of ethnic. For the newspaper Suara Keadilan, it can be seen that the issue was not given any media attention during the campaign period to be displayed in the newspaper. Table 1 demonstrates the findings of cross-release schedule and major issues.

Table 1. Table cross frequency issues according to newspapers

\begin{tabular}{lllllllll}
\hline \multicolumn{1}{c}{ Newspaper } & \multicolumn{2}{c}{ Utusan Malaysia } & \multicolumn{2}{c}{ Berita Harian } & \multicolumn{3}{c}{ Harakah } & \multicolumn{3}{c}{ Suara Keadilan } \\
& If) & $(\%)$ & (f) & $(\%)$ & (f) & (\%) & (f) & $(\%)$ \\
\hline 1. Candidates & 55 & 29.6 & 29 & 21.5 & 20 & 22 & 10 & 16.1 \\
2. Security & 38 & 20.4 & 38 & 28.1 & 4 & 4.4 & 5 & 8.4 \\
3. Election & 22 & 11.8 & 22 & 16.3 & 18 & 19.8 & 16 & 25.8 \\
4. Pakatan Rakyat & 16 & 8.6 & 13 & 9.6 & 11 & 12.1 & 10 & 16.1 \\
5. Goverment & 13 & 7 & 11 & 8.1 & 10 & 11 & 6 & 9.7 \\
Formation & & & & & & & & \\
6. Development & 14 & 7.5 & 10 & 7.4 & 5 & 5.5 & 4 & 6.5 \\
7. Rulling Party & 9 & 4.8 & 6 & 4.4 & 11 & 12.1 & 6 & 9.7 \\
8. Education & 6 & 3.2 & 2 & 1.5 & 3 & 3.3 & 2 & 3.2 \\
9. Religion & 4 & 2.2 & 1 & 0.7 & 6 & 6.6 & 1 & 1.6 \\
10. Ethnic & 6 & 3.2 & 2 & 1.5 & 1 & 1.1 & 2 & 3.2 \\
11. Media & 3 & 1.6 & 1 & 0.7 & 2 & 2.2 & 0 & 0 \\
Total & $\mathbf{1 8 6}$ & $\mathbf{1 0 0}$ & $\mathbf{1 3 5}$ & $\mathbf{1 0 0}$ & $\mathbf{9 1}$ & $\mathbf{1 0 0}$ & $\mathbf{6 2}$ & $\mathbf{1 0 0}$ \\
\hline
\end{tabular}

\section{Discussion and Recommendations}

\subsection{Overall Issues}

Overall results show that the analysis of tree nodes that are used in this study was appropriate, as it gives a more detailed guidance on the selection of a pattern formation issue, and it is related to the theoretical determination of 
the agenda that are applied in this study to find a detailed explanation of how treatment of a selected subisu until generation of an issue. This study supports the view by Littelejohn (2002) who claimed that the function of determining the agenda of the press through the process for selecting a media agenda on the issues discussed above, before setting the focus to real issues to be displayed to the audience. This item is also supported by Kim, Scheuffele and Shanahan (2002), which considers an analysis of news issues should form an implication of the study, indicated that the pattern of media agenda have relevance to pattern formation and the formation of perceptions of the news audience.

Another application of the theory of the determination of this agenda are the results of this theory have significant relationship with the issue, because the theory of this agenda clearly detailed the issues to sub-sub-categories to make the readers think of it in particular, and also able to provide information about the reporting of news that could affect and impact the readers. This supports the opinion of western scholars, who state that the use of the media agenda by searching selected sources until the explanation of how the agenda of the current agenda described an impact to society (Littlejohn, 2002). Thus, it can be concluded that, this study support the views of scholars on the treatment of news before the formulation of issues to be edited, so as to obtain a comprehensive study, and not only quantitative analysis alone. This shows that the issues presented in connection with the theory that explains the determination of the agenda's issue into sub-issues before being selected and edited and then shown to give effect to the voters. As a statement from Kim, Scheuffele and Shanahan (2002), a news story should form an issue because the implications of the study indicated that the pattern of media agenda has connections with the formation of pattern formation and perception of the news audience. Similarly, the opinion of Adrew (2002), who said the theory of the determination of the agenda chosen to look at a complex on the determination of the agenda, which involves several major agenda-setting process before being displayed.

Based on the four newspapers studied, there were 11 issues deemed most significant to study the candidates and issues, security and the election's agenda or the most prominent newspapers in the four newspapers. This is in contrast with the findings and small general election and scholars abroad earlier. This is because each of the issues are presented and debated in accordance with the current situation and do not rely on the findings of previous researchers, but according to the current situation. This supports the findings of the study by Chang (2002) who found that every time something happened and displayed by the media in accordance with the current situation and it depends on the owner of the newspaper. Media differences also become one of the display factors issues for each media such as websites and newspapers differ in views on these issues.

\subsection{Issues According to Newspapers}

Based on the fractional release, the results also show that there are differences between the four releases on issues that most frequently appear. There are similarities in Utusan Malaysia and Harakah in terms of the most important issues that appear during the election period when the two made a lot of press coverage of the candidates issues. Different in Berita Harian and Suara Keadilan because of safety issues and elections are covered by most journalists to appear in the newspapers. This supports the idea by Suhaimee (2008), the society feels that there are several issues that should be important, but was not published in the mainstream media, but in the alternative media. Similarly, the frequency of issues that are most widely displayed are based on the needs of their respective companies. The findings support the findings of researchers Ilias, Ismail and Norsham (2008); Ismail, Ngu and Saraswathy (2008); Suhaimee (2008) Christian (2004); Jeffrey (2009); and Melissa (2010) from the point of release fractions and other media fractions. This shows that each presentation of an issue depends on the media ownership so as to benefit them in addition to safeguarding the interests of political parties with interests in the media owned.

In addition, based on the fraction of the press and the issue, the study shows affinities with the goal of a newspaper. For example, the Utusan Malaysia newspaper's most featured issues where those relating to the candidates. This is because the company's mission is established to be a newspaper for the Malays. There is no wonder that Utusan Malaysia mainly displayed issues on the candidates that the newspaper felt should be discussed as the candidates involved in the election consists of the Malays. Hence the newspaper felt the need to show candidates that Malay readers could relate to, as well as being consistent with the objectives of the company that has an interest to the Malays.

Also Harakah, even though the original goal of the establishment of this newspaper is to increase the news related to religion, but results showed that less religious issues were displayed compared to the issue on candidates. This is because the function played by Harakah is to help and promote the candidate from the 
Pakatan Rakyat political party. Thus, they feel they must have the spirit to help to display related news in order to influence voters.

While in the Berita Harian newspaper, security issues were most prominently displayed during the campaign period, and this is related to inter-company sharing of Berita Harian and New Straits Times and most of the news published in Berita Harian newspaper from the New Straits Times were displayed. So the agenda set by the newspaper about the safety of most displayed for this security issue will appeal to readers who are of different race compared with Utusan Malaysia, which was established to focus on the Malay readers. Hence they feel that the security issue is designated as the main agenda to be displayed throughout the campaign period compared to other issues. This is to attract attention and influence the readers to be impacted by the agenda set. The newspaper Suara Keadilan most prominently displayed the issue of elections. It is compatible with the objectives of the company that owns the paper, which is the interest of the party that had links with politicians.

In summary, based on the frequency of news and issues, this study showed that the four newspapers carry the most prominent issues or the most viewed during the campaign period in accordance with the requirements of their respective owners. Only Utusan Malaysia and Harakah were similar in the issues highlighted though both newspapers support different ideologies and have different goals set the agenda to be featured on the audience. This statement supports previous findings because which indicated that there were differences in the issues presented by all the media studied.

\section{Conclusion}

To conclude, studies have shown that the media plays an important role in making coverage and publish issues regarding the election to the reader. In terms of categories of issues, the findings have been described in detail for sub-issues and a description of the formation of the main agenda of the sub-sub according to the issue. The frequency of findings in general showed that the issue related to the candidates were displayed by all four newspapers. However, the differences of the survey showed that newspapers are the most important issues of difference displayed by the four except Utusan Malaysia and Harakah that has similarities in the issues that were most displayed. In summary, it is concluded that the four daily newspapers publish according to the newspaper ownership. The newspaper owner's ideology affects the presentation of the issues in the newspaper.

\section{References}

Abbe, O. G. J., Herrnson, P., \& Peterson, K. (2003). Agenda setting in congressional elections: the impact of issues and campaigns on voting behavior. Political Research Quarterly, 56, 419-430.

Agee, K. W., Ault, P. H., \& Emery, E. (1997). Introduction to mass communication. Reading M. A. Longman.

Ahmad, N. (2006). Media trial 1 (1st ed.). Nilai: Kolej Universiti Islam Malaysia.

Bakar, A. L. A. (1998). The role of media in the Federal election. Shah Alam: Fajar Bakti Sdn Bhd Publisher.

Berelson, B. (1971). Content Analysis in communication Research, Glencoe. Illinois: The Free Press.

Chang, P. T. (2002). Mass media and BN hegemony: A case study on the role of media in financial management in Malaysia 1997. PhD. Thesis. Bangi: Universiti Kebangsaan Malaysia.

Christian, S. (2004). Content analysis of newspaper and television advertisements: A case study of Taiwan's 2004 Presidential Election. Modern East Asia, 3(4), 1-19.

Cohen, B. C. (1963). "The press and foreign policy". Princeton, NJ: Princeton University Press p.

Diah, A. H. M. (2002). Press Politics and Propaganda: A Case Study of Press Coverage Harakah Before and After Events Sacked Anwar Ibrahim. Master Thesis. Bangi: Universiti Kebangsaan Malaysia.

Everrete, E. D., Arnold, H. I., \& Donald, M. G. (1978). Enduring issues in mass communication. St. Paul: West Pub. Co.

Hamidi, A. Z. (2008). BN manifesto as Malay-language newspaper agenda during the election campaign. PhD. Thesis. Serdang: Universiti Putra Malaysia.

Hashim, M. S. (1991). The flow of international news in Malaysia. Kuala Lumpur: Dewan Bahasa dan Pustaka serta Kementerian Pendidikan Malaysia.

Hashim, M. S. (1996). Press and power: the development of press system in Malaysia since 1806. Kuala Lumpur: Penerbit Universiti Malaya.

Hayes, D. (2008). Does the messenger matter: candidate-media agenda convergence and its effect on voter issue salience. Political Research Quarterly, 16, 134-146. http://dx.doi.org/10.1177/1065912907306472

Holsti, O. R. (1969). Content Analysis for Social Science and Humanities. Reading: Addison-Wesley Publishing. 
Idid, S. A. (1992). Methods of communication and social science research. Kuala Lumpur: Dewan Bahasa dan Pustaka.

Ismail, M. (2008, August). The results measure the current political of Permatang Pauh. Berita Harian. Retrieved from http://blis.bernama.com

Jeffrey, D. M. (2009). Racial Framing in the 2008 Presidential Election: A Content Analysis of Geographically Diverse Newspapers and the Framing of Barack Obama. Master Thesis. Department of Communication College of Liberal Arts.

Kassim, M. S. (1994). Mass communication issues: The role of news. Kuala Lumpur. Dewan Bahasa dan Pustaka and Ministry of Education Malaysia

Kim, S. H., Scheufele, D. A., \& Shanahan, J. (2002). "Think about it this way: attributeagenda setting function of the press and the public's evaluation of a localissue“. Journalism and Mass Communication Quarterly, 79, 7-25 (Spring). http://dx.doi.org/10.1177/107769900207900102

Lawrence, R. G., \& Birkland, T. A. (2004). "Guns, hollywood and school safety: definingthe school-shooting problem across public arenas". Social Science Quarterly, 85, 1193-1207. http://dx.doi.org/10.1111/j.0038-4941.2004.00271.x

Littlejohn, S. W. (2002). Theories of human communication (7th ed.). Belmont: Wadsworth.

McCombs, M. E. (1997). "Candidates' images in Spanish Elections: Second-level agenda setting effects." $\begin{array}{lllll}\text { Journalism and Mass Communication } & \text { Quarterly, 74, }\end{array}$ http://dx.doi.org/10.1177/107769909707400404

McCombs, M. E., \& Shaw, D. L. (1972). The agenda-setting function of the mass media. Public Opinion Quarterly, 36, 176-187. http://dx.doi.org/10.1086/267990

Melissa, K. (2010). A content analysis of Elite U.S. Newspapers' coverage of Iran 1979 and 2005. Master Thesis. Florida: College of Sciences, University of Central Florida.

Omar, F. A. (2002, July 29). Media 'alternative' versus 'mainstream'. Malaysiakini. Retrieved from http://www.malaysiakini.com

Pamela, E., \& Gregory, M. M. (2000). Political processes and local newspaper coverage of protest events: From selection bias to triadic interactions. Presented at the "Collective Behavior" session of the American Sociological Association meeting Atlanta, Georgia.

Rahman, Z. A., Othman, M. R., Ghazali, A. S., \& Badaruddin, S. (2008). The question and the meaning behind the Permatang Pauh by election. Malaysia Politics Seminar, 487-501.

Ramle, N. A. (2006). Media trial 1 (1st ed.). Development of the press in Malaysia. Nilai: Kolej Universiti Islam Malaysia.

Saahar, S. (2008). The major issues before, during and after the General Election 12: A content analysis of political blogs selected Malaysia. Jebat, 35, 81-96.

Salleh, I. M., Sualaman, I., \& Firdaus, N. (2008). Media and elections: A case study in the parliamentary Permatang Pauh, Penang. Report IRDC, UiTM Shah Alam.

Saman, M. A. (1995). Writing and newspapers. Kuala Lumpur: Dewan Bahasa dan Pustaka.

Shah, I. A., Haron, S., Nordin, N., Badaruddin, S., MatKib, M. Z., Sarwan, Y., Suyurno, S. S., Dahalan, Z., Muis, M., \& Abidin, S. Z. (2009). And behavioral issues during election campaigns parliamentary constituency. In W. H. Kabul, S. Haron, M. Z. MatKib \& A. K. Rosline (Eds.), Politics Proceedings Malaysia: Malaysia's political landscape post-election to-12. Sabah: University Publication Centre (UPENA), Universiti Teknologi MARA.

Somiahl, V., Hamzah, A., Ariffin, M. Y. M., \& Aziz, A. A. (2010). News coverage of Indonesia in Malaysia: analysis of Utusan Malaysia and Berita Harian. Journal of Media Studies Malaysia, 12(1).

Sualman, I., Ngu, T. H., \& Saraswathy, C. (2008). General Election 2008: Content Analysis Study on Selected Press. Faculty of Communication and Media Studies, UiTM Shah Alam.

Sufeno, M. (2004). Credibility of the news media in channeling political: Audience research and print media. Master thesis. Bangi: Universiti Kebangsaan Malaysia.

\section{Copyrights}

Copyright for this article is retained by the author(s), with first publication rights granted to the journal.

This is an open-access article distributed under the terms and conditions of the Creative Commons Attribution license (http://creativecommons.org/licenses/by/3.0/). 